\title{
Impact of Chinese anthropogenic emissions on submicrometer aerosol concentration at Mt. Tateyama, Japan
}

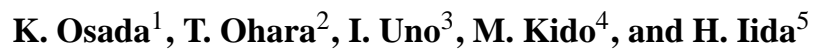 \\ ${ }^{1}$ GSES, Nagoya University, Nagoya, Japan \\ ${ }^{2}$ National Institute for Environmental Studies, Tsukuba, Japan \\ ${ }^{3}$ Research Institute for Applied Mechanics, Kyusyu University, Fukuoka, Japan \\ ${ }^{4}$ Toyama Prefectural Environmental Science Research Center, Imizu, Japan \\ ${ }^{5}$ Tateyama Caldera SABO Museum, Tateyama, Japan
}

Received: 3 July 2009 - Published in Atmos. Chem. Phys. Discuss.: 6 August 2009

Revised: 19 November 2009 - Accepted: 26 November 2009 - Published: 2 December 2009

\begin{abstract}
Rapid Asian economic development might engender secondary impacts of atmospheric aerosol particles over the western Pacific after conversion of gaseous pollutants such as $\mathrm{SO}_{2}$. To elucidate changes in aerosol concentrations in leeward areas undergoing remarkable industrialization, the number-size distributions of submicrometer $(0.3-1.0 \mu \mathrm{m})$ aerosols were measured at Murododaira $\left(36.6^{\circ} \mathrm{N}, 137.6^{\circ} \mathrm{E}\right.$, $2450 \mathrm{~m}$ a.s.l.) on the western flank of Mount Tateyama in central Japan during January 1999-February 2009. Nighttime data obtained from 2400 to 0500 were used to analyze free-tropospheric aerosol concentration. Monthly average volume concentrations were calculated for months with $>50 \%$ daily data coverage. Volume concentrations of submicrometer aerosols were high in spring to early summer and low in winter. Significant increasing trends at $95 \%$ confidence levels were found for volume concentrations in winter-spring. Simulated monthly anthropogenic aerosol concentrations at Mt. Tateyama from results of regional aerosol modeling with emission inventory up to 2005 showed seasonal variation and winter-spring increasing trends similar to those of observed aerosol concentration. According to the model analyses, the contribution of anthropogenic aerosol concentrations derived from China was high during winter-spring (60-80\% of total anthropogenic aerosols at Mt. Tateyama). This accords with the increasing trend
\end{abstract}

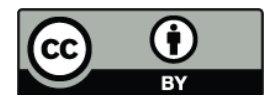

Correspondence to: $\mathrm{K}$. Osada (kosada@nagoya-u.jp) observed for winter-spring. Because $\mathrm{SO}_{4}^{2-}$ is the dominant component of total anthropogenic aerosols, these results suggest that increasing anthropogenic emissions, especially for $\mathrm{SO}_{2}$, in China, engender enhancement of submicrometerdiameter aerosols over Japan during winter-spring.

\section{Introduction}

Free tropospheric aerosol particles play an important role in the long-range transport of anthropogenic pollutants and in direct and indirect effects on the radiation balance of the earth. Rapid Asian economic development might affect atmospheric pollution, such as increasing $\mathrm{SO}_{2}$ and $\mathrm{NO}_{\mathrm{x}}$ (Streets et al., 2003; Akimoto, 2003; Ohara et al., 2007). These gaseous species might be converted to aerosols during atmospheric transport, engendering secondary impacts on aerosol concentrations in leeward regions such as the Western and Northern Pacific regions. Prospero et al. (2003) reported an increasing trend from 1981 to the mid-1990s for non-sea-salt (nss) $\mathrm{SO}_{4}^{2-}$ and $\mathrm{NO}_{3}^{-}$in aerosols at Midway Island in the North Pacific. Their analysis ended at year 2000 with large variability and showed an even slightly decreasing tendency in the late 1990s. On the other hand, satellite data have shown a recent increase of an $\mathrm{NO}_{2}$ column amount over China, which has been compared with results of numerical models (Richter et al., 2005; van der A et al., 2006, 2008; He et al., 2007; Uno et al., 2007a). Increased $\mathrm{NO}_{\mathrm{x}}$ emissions in

Published by Copernicus Publications on behalf of the European Geosciences Union. 


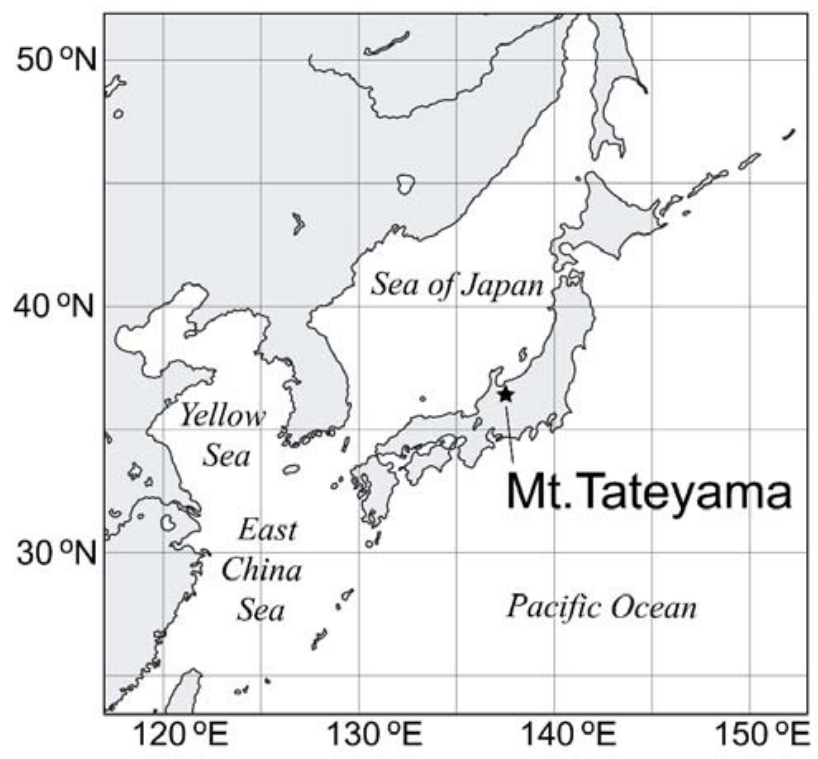

Fig. 1. Map of Mount Tateyama, Japan.

China might increase aerosol nitrate concentration and, consequently, wet and dry deposition flux of total nitrate in and around the Japan Islands (Uno et al., 2007b). The once flat $\mathrm{SO}_{2}$ emission trend in China (27.1 and 27.6 Mt in 1995 and 2000 , respectively) of the late 1990s has turned upward since 2000 (e.g. 36.6 Mt in 2003; Ohara et al., 2007). Although some reports (Huebert et al., 2001; Prospero et al., 2003) have described long-term anthropogenic aerosol impacts at far leeward areas of China, aerosol concentrations have not been described for the area since 2000 .

In situ measurements at a high-elevation site might provide valuable data to elucidate year-round free tropospheric aerosols, including rainy days (e.g. Nyeki et al., 1998; Huebert et al., 2001; Osada et al., 2003). Our previous report on free tropospheric aerosols over Japan described a clear seasonal variation of submicrometer aerosols - high in summer and low in winter - based on nearly 3 year observation from 1999 (Osada et al., 2003).

To elucidate interannual variations of submicrometer aerosols over Japan, this paper presents variations of submicrometer aerosols during 10 years at Murododaira $\left(36.57^{\circ} \mathrm{N}, 137.60^{\circ} \mathrm{E}, 2450 \mathrm{~m}\right.$ a.s.l.), on the western flank of Mt. Tateyama. We compare aerosol data with regionally simulated anthropogenic aerosols including $\mathrm{SO}_{4}^{2-}$ concentrations for Mt. Tateyama. We discuss seasonal variation of contribution for anthropogenic aerosols derived from China and the importance of $\mathrm{SO}_{2}$ emissions in China for aerosols at Mt. Tateyama to explain the increasing trend for winterspring in aerosol concentrations.

\section{Observation, data treatment, and numerical model}

Number-size distributions of atmospheric aerosol particles were measured using a laser particle counter (KC 01C and KC 01D; Rion Co., Ltd.) from 27 January 1999 at the Hotel Tateyama in Murododaira $\left(36.57^{\circ} \mathrm{N}, 137.60^{\circ} \mathrm{E}\right.$, $2450 \mathrm{~m}$ a.s.1.) on the western flank of Mount Tateyama in central Japan (Fig. 1). The laser particle counter (LPC) there measures the number of aerosol particles for five size ranges: $>0.3,0.5,1.0,2.0$, and $5.0 \mu \mathrm{m}$ diameter. It is calibrated every year by the manufacturer using standard polystyrene latex particles. The coincidence correction was made at high concentrations of greater than $10^{5}$ particles per liter. The sample air humidity was mostly less than $40 \%$ because the room temperature was always higher than outside temperature. Aerosol concentrations are reported as the values of standard temperature $\left(25^{\circ} \mathrm{C}\right)$ and pressure $(1 \mathrm{~atm})$. Losses of aerosol particles resulting from diffusion and gravitational settling before entering the LPC from the outside were estimated as less than $10 \%$ for submicrometer $(0.3-1.0 \mu \mathrm{m})$ particles. During the winter monsoon period (November-April), strong northwesterly winds prevailed with frequent snowfalls with rime ice. A snow-clogging preventer resembling the "Frisbee sampler" described by Heidam et al. (1993) was installed at the tip of the inlet tube.

Upslope valley winds and downslope mountain winds occur on the slopes of Mt. Tateyama. Upslope valley winds are caused by surface heating of the mountain slopes by solar radiation during the day. Downslope mountain winds are caused by radiative cooling of the mountain surface during the night (Whiteman, 2000). Dense cooler air flows down the mountain slope, flushing the mountain surface with clean air from the free troposphere. To select free tropospheric data at Mt. Tateyama, the hourly data of aerosol number concentrations and $\mathrm{O}_{3}$ concentrations were analyzed previously (Osada et al., 2003). Increased concentration of aerosols during daytime was associated with vertical upward transportation of pollutants from the lowland area near the mountain. Lower concentrations at nighttime from 24:00 to 05:00 LT (local time) were attributed to the subsidence of clean air from the free troposphere aloft (Osada et al., 2003). Consequently, nighttime data from 24:00 to 05:00 were used for this study to analyze free-tropospheric conditions. For the submicrometer $(0.3-1.0 \mu \mathrm{m})$ size range, monthly average volume concentrations were calculated for the month with $>50 \%$ coverage of daily nighttime data. In all, 90 monthly data were obtained for this period (122 months: January 1999_ February 2009).

The three-dimensional regional-scale chemical transport model (Uno et al., 2005) used for this study was based on the Models-3 Community Multiscale Air Quality (CMAQ) version 4.4 modeling system released by the US Environmental Protection Agency (Byun and Schere, 2006). This model is driven by meteorological fields generated by the Regional Atmospheric Modeling System (RAMS) version 4.4 
(Pielke et al., 1992). The horizontal model domain for the CMAQ simulation is $6240 \times 5440 \mathrm{~km}$ on a rotated polar stereographic map projection centered at $25^{\circ} \mathrm{N}, 115^{\circ} \mathrm{E}$, with a grid resolution of $80 \times 80 \mathrm{~km}$. For vertical resolution, we used 14 layers up to $23 \mathrm{~km}$ a.s.l. in the sigma-z coordinate system. We adopted the Statewide Air Pollution Research Center (SAPRC)-99 scheme (Carter, 2000) for gas-phase chemistry; this scheme uses 72 chemical species and 214 chemical reactions, including 30 photochemical reactions. For aerosol calculations, we applied the third-generation CMAQ aerosol module (AERO3), which includes the Secondary Organic Aerosols Model (SORGAM) (Schell et al., 2001) as a secondary organic aerosol model, ISORROPIA (Nenes et al., 1998) as an inorganic aerosol model, and the piecewise parabolic method (PPM) (Binkowski and Shankar, 1995) as the regional particulate model.

We conducted two sets of numerical experiments. First, we performed simulations to obtain aerosol concentrations at Mt. Tateyama for 1 January 1999-31 December 2008 (control run). Second, we conducted a perturbation run with emissions from China set to zero to estimate the contribution from Chinese anthropogenic emissions to aerosol concentrations at Mt. Tateyama. We defined the Chinese contribution as the difference between the control run and the perturbation run. Both runs used the same meteorological field and initial and boundary conditions for chemical tracers. Meteorological fields for each year were generated using RAMS with initial and boundary conditions defined by the National Centers for Environmental Prediction - National Center for Atmospheric Research (NCEP-NCAR) Reanalysis 1 datasets (http://www.cdc.noaa.gov/cdc/data.ncep. reanalysis.html) (Kalnay et al., 1996; Kistler et al., 2001). The reanalysis datasets have spatial resolution of $2.5^{\circ} \times 2.5^{\circ}$ and temporal resolution of $6 \mathrm{~h}$. The initial fields of chemical compounds were prepared by the initial conditions processor (ICON) of the CMAQ modeling system (Byun and Schere, 2006). The influence of the initial conditions was eliminated during the 3-month spin-up period. The monthly averaged lateral boundary conditions for most chemical tracers were obtained from a global chemical transport model: Chemical AGCM for Study of Atmospheric Environment and Radiative Forcing (CHASER; Sudo et al., 2002).

For these simulations, we prepared datasets for anthropogenic emissions of sulfur dioxide $\left(\mathrm{SO}_{2}\right)$, nitrogen oxides $\left(\mathrm{NO}_{\mathrm{x}}\right)$, carbon monoxide $(\mathrm{CO})$, non-methane volatile organic compounds (NMVOC), black carbon, organic carbon, and ammonia $\left(\mathrm{NH}_{3}\right)$ using the Regional Emission Inventory in Asia (REAS, ver. 1.1) (Ohara et al., 2007). The REAS datasets include most anthropogenic sources such as fuel combustion and industrial processes for 1981-2003. We extended the datasets until 2005 using the same methodology as that used by Ohara et al. (2007). We included new data related to energy consumption and industrial activities (e.g. International Energy Agency, 2007; United Nations, 2005, 2006). For parameters such as emission factors and

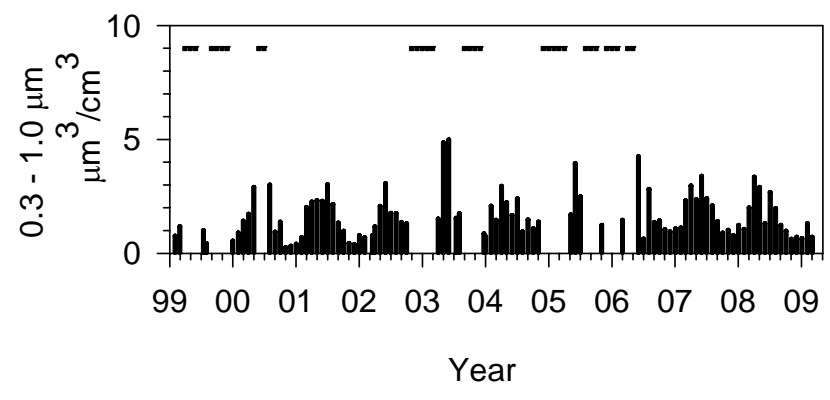

Fig. 2. Monthly volume concentration of submicrometer aerosols at Mt. Tateyama. Horizontal bars represent periods of missing data.

removal efficiencies, we adopted those from 2003. The emissions were fixed at 2005 level for the remainder of the period. Seasonal variation is not considered in the REAS database. For volcanic $\mathrm{SO}_{2}$ emissions, excluding the Miyakejima Volcano, and emissions from biomass burning, we used climatological inventories from Streets et al. (2003). For the Miyakejima Volcano, which erupted in the summer of 2000, we used the annual mean $\mathrm{SO}_{2}$ emissions for 2002 from Kazahaya et al. (2003).

This modeling system has been used for analyzing particulate sulfate and sulfur depositions (Katayama et al., 2008), particulate nitrogen and nitrogen depositions (Uno et al., 2007b), and tropospheric ozone (Yamaji et al., 2006, 2008) over eastern Asia, including Japan. In these studies, the simulated results show good agreement with observations.

\section{Results and discussion}

\subsection{Temporal variations of submicrometer aerosols}

Figure 2 shows interannual variation of monthly averages on submicrometer aerosols at Mt. Tateyama. Horizontal bars in the panel show the month of the insufficient data number. The largest spikes during May-June 2003 might have resulted from the Siberian boreal forest fires as detected at Mt. Fuji $(3776 \mathrm{~m})$, ca. $160 \mathrm{~km}$ southeast of Mt. Tateyama (Kaneyasu et al., 2007). Although data gaps and such spikes hamper seasonal and interannual variations, the winter minimum is apparently increasing slightly. For example, winter minima for 2000-2001 and 2001-2002 were 0.27 (November 2000) and 0.40 (December 2001) $\mu \mathrm{m}^{-3} \cdot \mathrm{cm}^{-3}$, whereas winter minima for 2006-2007 (December 2006) and 2007-2008 (December 2007) were, respectively, 0.98 and $0.82 \mu \mathrm{m}^{-3} \mathrm{~cm}^{-3}$. Seasonal variations with higher volume concentrations in spring to early summer were also noticed.

Figure 3 presents average monthly seasonal variation of submicrometer aerosol volume. The volume concentration of submicrometer aerosols was high, with large variation in late spring to early summer (April-July) and low variation in winter (November-February) as reported previously (Osada 
Table 1. Results of least-squares fitting between the monthly volume concentration and year at the $95 \%$ confidence level.

\begin{tabular}{lrccc}
\hline month & $n^{1}$ & $r^{2}$ & $b^{3}$ & $\sigma^{4}$ \\
\hline Dec & 5 & 0.92 & 0.052 & 0.013 \\
Dec + Jan & 12 & 0.69 & 0.037 & 0.012 \\
Mar + Apr & 15 & 0.56 & 0.033 & 0.014 \\
Nov + Dec & 12 & 0.70 & 0.054 & 0.017 \\
Jan + Feb* & 14 & 0.65 & 0.025 & 0.009 \\
\hline
\end{tabular}

1 number of data;

2 correlation coefficient;

3 slope of regression;

4 standard deviation of the slope.

* Excluding data on February 2004. Including these data, $r$ was 0.51 and the correlation was not significant at the $95 \%$ confidence level.

Fitting was performed using logarithms of monthly volume data.

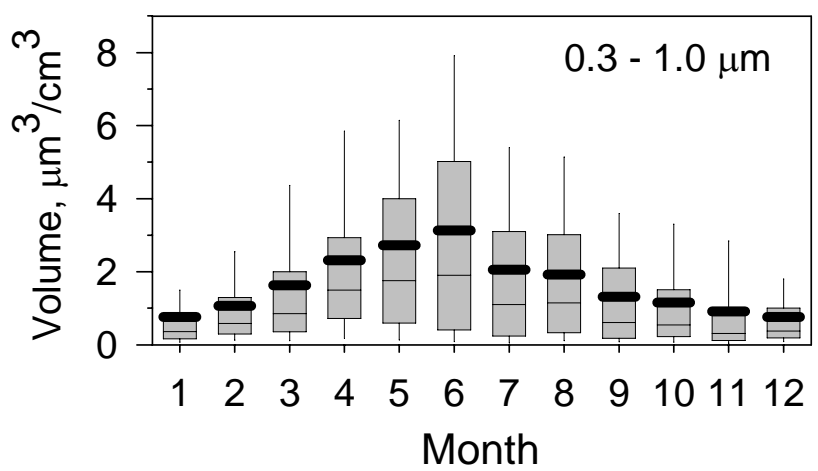

Fig. 3. Monthly box plot of submicrometer aerosol volume concentration. The lower boundary of the box shows the 25 th percentile, the line within the box marks the median, and the upper boundary of the box shows the 75th percentile. Whiskers above and below the box represent the 90 th and 10th percentiles. The mean is also portrayed as a thick line.

et al., 2003). One might expect from the higher concentration in the warm season is that the site might still be influenced by upslope winds even during the night, disturbing the pristine free tropospheric air masses locally. If this were the main cause of increasing submicrometer volume concentration in the warm season, then the maximum volume concentration would be found in August, not in June, because of local weather. Weather in August at Mt. Tateyama is more suitable than that in June for forming strong and persistent effects of valley winds. According to Osada et al. (2003), the seasonal variation of submicrometer aerosol concentration was attributed to the change in the dominant air mass system around Japan based on backward air trajectories from Mt. Tateyama. In winter (November and February), the dominant air flow was derived from the far west (west of $100^{\circ} \mathrm{E}$ )
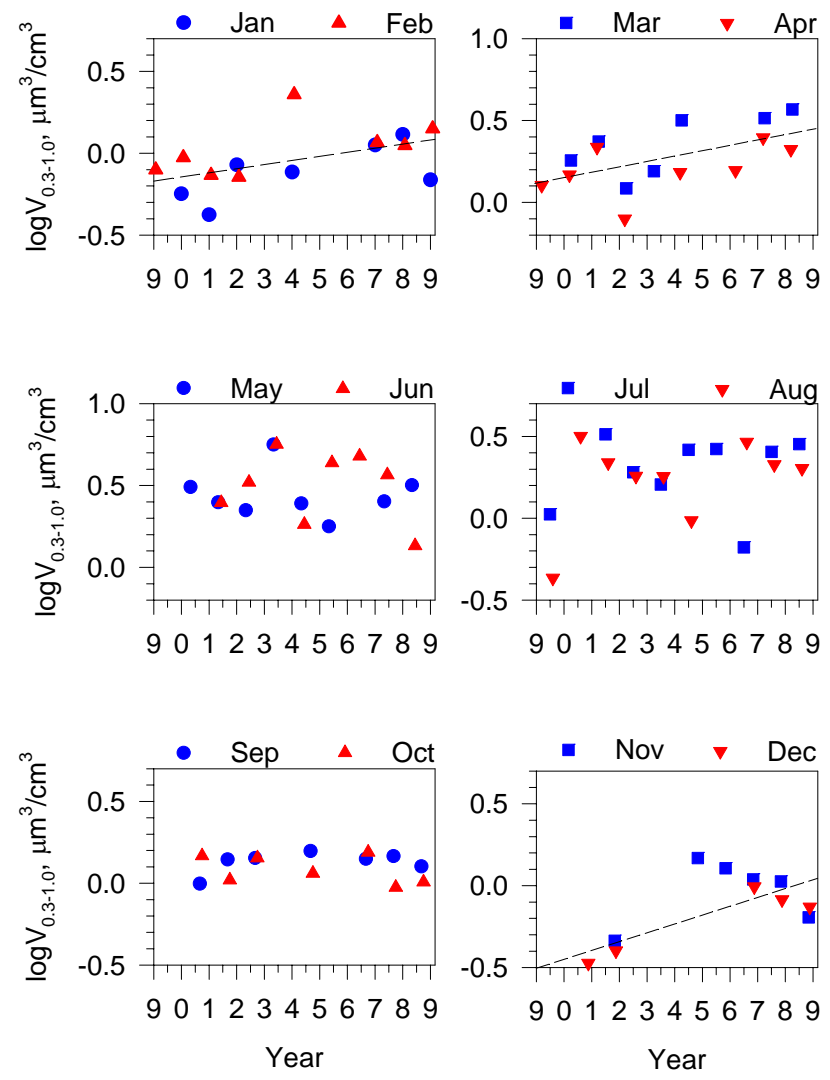

Fig. 4. Interannual variations of monthly submicrometer aerosol volume data at Mt. Tateyama. Linear regressions represented by dotted lines were calculated for logarithms of the data using 2 months in the panel.

of Japan. In early summer (June), stagnant slow air flow was detected around the coastal area of the Yellow Sea and around the Japanese islands. The Yellow Sea coastal area is a vast source region of anthropogenic $\mathrm{SO}_{2}$ (Streets et al., 2003; Ohara et al., 2007). Consequently, meteorological conditions in early summer are suitable for forming submicrometer $\mathrm{SO}_{4}^{2-}$ particles through conversion of anthropogenic $\mathrm{SO}_{2}$ during slow transport from the coastal area of the Yellow Sea and around Japan (Uno et al., 1998; Osada et al., 2003). The seasonal variation and its variation of aerosol source areas will be discussed later in greater detail.

As described previously, the winter minimum is apparently increasing slightly. Spikes hamper identification of temporal variations. Therefore, data for the same month in different years were examined. Figure 4 portrays interannual variations of monthly submicrometer aerosols. Results of least-squares fitting between monthly submicrometer volume data and yearly data are also given in Table 1 . The aerosol concentrations are approximately log-normally distributed. Therefore, the fit was performed on the logarithms of the data. Only data for December showed a significant trend at a $95 \%$ confidence level. On the other hand, progress 
Table 2. Results of the Mann-Kendall test of monthly volume concentration.

\begin{tabular}{lcccc}
\hline month & $n^{1}$ & $\tau^{2}$ & $Z^{3}$ & $\mathrm{CL}^{4}$ \\
\hline Jan + Feb & 15 & 0.37 & 1.93 & 90 \\
Mar + Apr & 15 & 0.49 & 2.53 & 95 \\
\hline
\end{tabular}

1 number of data;

2 Kendall's correlation coefficient;

3 normal test statistic;

4 confidence level in $\%$.

of seasons at a particular location might vary from year to year. Therefore, we further investigated interannual trends in two-month combinations such as December and January, and November and December. Increasing trends of submicrometer aerosols at a 95\% confidence level were found for the combinations of December-January, March-April, and November-December. For the trend on January-February, the correlation coefficient $(r)$ was low $(0.51)$ with a significance level of $5.1 \%$ using all data. However, the $r$ was increased to 0.65 with a significance level of $1.2 \%$ for data excluding February 2004. The reason for the extremely high concentration at February 2004 is not known. Figure 4 shows that no clear trend was apparent in other combinations of months.

Because aerosol volume data might not conform to a normal distribution and because our data include gaps in time series, we also used the Mann-Kendall test, a nonparametric method, to detect trends (Gilbert, 1987; Collaud Coen et al., 2007). Results of the test are given in Table 2. Using singlemonth data, no case of significance was found at a $90 \%$ confidence level. However, combinations of January-February and March-April respectively showed upward trends at $90 \%$ and $95 \%$ confidence levels.

Factors related to the increasing trend in winter to spring observed at Mt. Tateyama can be classified into two: those causes related to the increase and those related to seasonality. Both are examined in the next section.

\subsection{Factors relating to increasing trend and seasonal preference in winter-spring}

Aerosol concentrations might be decreased by precipitation scavenging near the site. Our observations were made at a high-elevation site: in-cloud nucleation scavenging might reduce submicrometer aerosol concentration near the site. Figure 5 shows an example of precipitation damping for aerosol concentration during summer, showing a phase relation of low volume concentration under precipitation conditions. Although rain data at Murododaira were available for summer, no year-round record of precipitation at the site exists. On the other hand, the boundary layer height

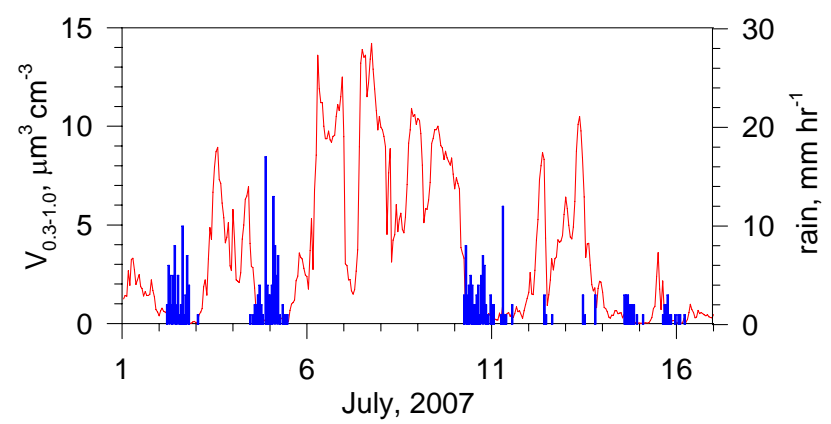

Fig. 5. Temporal variations of submicrometer volume concentration (red line, left axis) and hourly precipitation amounts (blue bar, right axis) at Murododaira, Mt. Tateyama in July 2007.

during daytime might influence nighttime aerosol data as expected in summer months. Conditions of ground heating near the site related to the boundary layer height might change with the shifting occurrence of precipitation type from snow to rain around the mountain. Although air temperature at Murododaira during winter is well below zero, the type of precipitation at the foot of the mountain depends on the air temperature there: increasing winter temperatures might reduce snow accumulation, enhance areas of bare ground and consequently increase surface heating, thereby engendering an increase of the boundary layer height in winter. For that reason, data (http://www.jma.go.jp/jma/indexe.html, last access: 2 December 2009) at a meteorological station (Kamiichi, $296 \mathrm{~m}$ a.s.l., about $25 \mathrm{~km}$ northwest of Murododaira) near the site were used to elucidate the interannual trends of precipitation amounts and air temperature. Figure 6 shows monthly precipitation and air temperature at Kamiichi for November, December, January, February, March, and April, which are months showing upward trends for aerosol volume concentrations, as presented in Table 1. Neither variable shows a significant trend, suggesting that the extent of local precipitation scavenging and ground heating during winterspring did not change during this period.

Increasing anthropogenic emissions such as $\mathrm{SO}_{2}$ in eastern Asia, especially in China, might engender the increase of anthropogenic aerosols such as $\mathrm{SO}_{4}^{2-}$ aerosols over Japan, which is located leeward of China. Figure 7 portrays yearly $\mathrm{SO}_{2}$ emissions in China (red vertical bars in the upper panel; Ohara et al., 2007 with update to 2005), simulated aerosol concentrations for various components based on control (including all emissions in the model, denoted as CNTL total hereinafter) and perturbation (without emissions from China) runs, and the fraction (\%) of total aerosols derived from China (blue line in the lower panel) in CNTL total aerosols at Mt. Tateyama based on numerical experiments using the chemical transport model. Aerosol concentrations in the middle panel are (1) total aerosol concentrations of the control run (blue line, CNTL total) calculated using all emissions in the model (see Sect. 2), (2) total aerosol concentration 


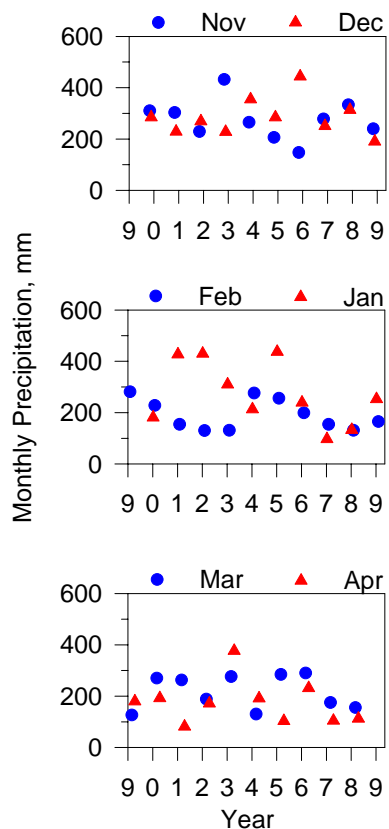

Fig. 6. Interannual variations of monthly precipitation amount (left column) and air temperatures (right column) for winter-spring at Kamiichi, near Mt. Tateyama.

derived from China (red line, China total), (3) $\mathrm{SO}_{4}^{2-}$ concentration from China (green line, China $\mathrm{SO}_{4}^{2-}$ ), and (4) $\mathrm{NH}_{4}^{+}$

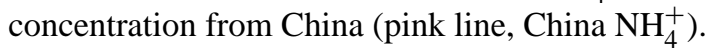

An increasing trend is evident in yearly $\mathrm{SO}_{2}$ emissions in China, at least before 2005. The yearly rate of increasing $\mathrm{SO}_{2}$ emission was low in the early period $(-2002)$ but it increased after 2002. Rapid industrial development in China has necessitated consumption of fossil fuels including sulfur-containing materials on an enormous scale. However, increasing rates of $\mathrm{SO}_{2}$ emission in China will be reduced through application of recent pollution control technology and phasing out of small thermal power plants. Consequently, $\mathrm{SO}_{2}$ emissions in China are difficult to estimate for recent years. However, at least it can be said that the yearly rate of increase in $\mathrm{SO}_{2}$ emissions has remained positive during 1999-2005.

Estimated aerosol concentrations for CNTL total and China total showed clear seasonal variations: high in summer and low in winter. Seasonal variation was not given in emission data. Therefore, these seasonal variations of aerosol concentration are attributed to changes in transport and aerosol formations relating to meteorological situations that vary seasonally in eastern Asia. Both simulated seasonal variations agree very well with those of submicrometer aerosols at Mt. Tateyama, suggesting that a major factor controlling seasonal variation in aerosol concentration at Mt. Tateyama is the contribution of aerosols from China. The contribution of aerosols from China at Mt. Tateyama was always high $(60-80 \%)$ in winter-spring and low (20-80\%)
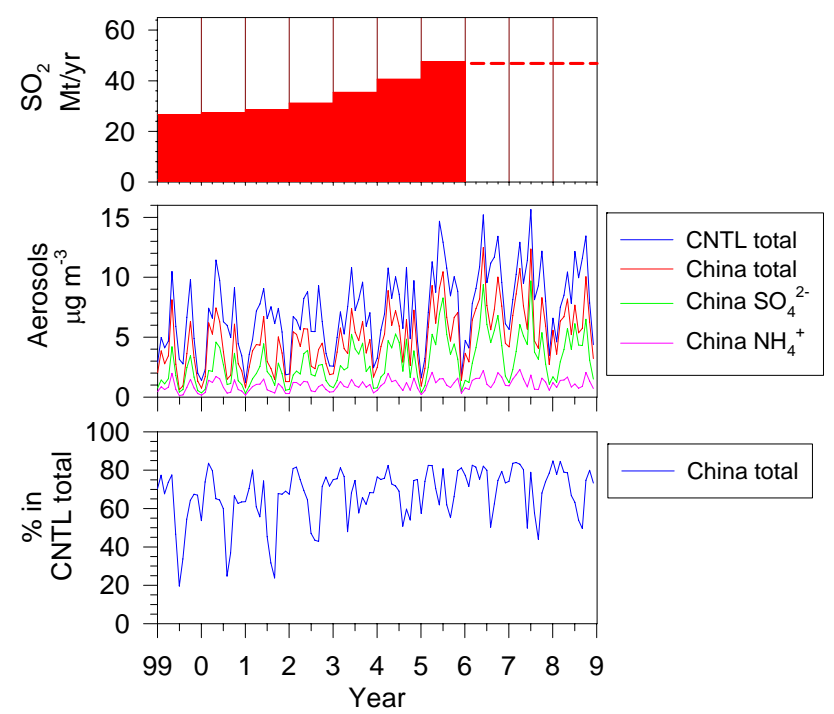

Fig. 7. Upper panel: Yearly $\mathrm{SO}_{2}$ emission in China (red vertical bars in the upper panel; Ohara et al., 2007 with update to 2005), Middle panel: simulated total aerosol concentrations with all sources (CNTL total, blue line), Chinese contribution of total (red line), $\mathrm{SO}_{4}^{2-}$ (green line), and $\mathrm{NH}_{4}^{+}$(pink line) aerosols, and Lower panel: the fraction (\%) of total aerosols derived from China in all aerosols of the CNTL run (blue line in the lower panel) at Mt. Tateyama based on numerical experiments using the chemical transport model.

- with large variation - in other seasons. The higher Chinese contribution to CNTL total aerosols might engender a more direct link of emission trends (such as $\mathrm{SO}_{2}$ ) in China to the secondary production of anthropogenic aerosols (such as $\mathrm{SO}_{4}^{2-}$ aerosols) in the atmosphere. This agrees well with observed seasonality of the increasing trend of submicrometer aerosols during winter-spring. In fact, a slightly increasing trend in the winter minimum was also well simulated in the model results.

Although $\mathrm{SO}_{2}$ emissions from Miyakejima Volcano were included after 2000, its effect on $\mathrm{SO}_{4}^{2-}$ and total aerosol concentrations was not discernable in Fig. 7. This apparent lack of effect might be attributed to the low impact of $\mathrm{SO}_{2}$ from Miyakejima Volcano on total $\mathrm{SO}_{2}$ inventory because $\mathrm{SO}_{2}$ emissions from Miyakejima Volcano were estimated about 1/7 of Chinese emissions for 2002 (Katayama et al., 2008). The largest spikes (May-June 2003) detected in Fig. 2 are not reproduced in Fig. 7. Large variations in seasonal and year-to-year emissions from open burning are recognized as well as temporal variations in emissions from boreal forest fires (Streets et al., 2003; van der Werf et al., 2006). Our modeling system does not incorporate these temporal variations. Therefore, simulated EC and OC concentrations might not reproduce such temporal variations. Another direction of this study will be to include various temporal variations in greater detail. 
On the other hand, simulated peak concentrations during the warm season after 2005 are slightly higher than those before 2005, showing a gradual increase since 2003. This increase might be attributed to the increase of $\mathrm{SO}_{2}$ emissions in China. However, such differences in maximum values during the warm season were not noted in observations (Fig. 2). As discussed later, source areas of aerosols during the warm season are highly variable. Considering the complex topography in Japan and various contributions of source areas, possible reasons for this discrepancy might include the coarser spatial resolution $(80 \mathrm{~km} \times 80 \mathrm{~km})$ of our modeling system. Similarly, changes in regional atmospheric stability and vertical motions related to changes in land use and light absorbing aerosol concentrations in China (Menon et al., 2002) might not be fully reproduced.

Among various components considered in the model, concentrations of $\mathrm{SO}_{4}^{2-}$ aerosols of the CNTL run comprise $59 \%$ of the CNTL total aerosol amount, on average, at Mt. Tateyama. Figure 7 shows that seasonal variation of $\mathrm{NH}_{4}^{+}$aerosols is similar to $\mathrm{SO}_{4}^{2-}$ and total aerosols, but the concentration of $\mathrm{NH}_{4}^{+}$is much lower. Other components $\left(\mathrm{NO}_{3}^{-}, \mathrm{EC}\right.$, and $\left.\mathrm{OC}\right)$ show similar seasonal variations and slightly increasing trends, but they contribute a minor portion of total concentration as well. Actually, $\mathrm{NH}_{4}^{+}$tends to associate with $\mathrm{SO}_{4}^{2-}$ in aerosols. Therefore, concentrations of $\mathrm{SO}_{4}^{2-}+\mathrm{NH}_{4}^{+}$aerosols derived from China comprise $52 \%$ of CNTL total aerosols and 78\% of aerosols derived from China at Mt. Tateyama. According to the results for submicrometer aerosols measured at Mt. Tateyama in winter and spring (Kido et al., 2001), the respective concentrations of $\mathrm{SO}_{4}^{2-}+\mathrm{NH}_{4}^{+}$among all ionic constituents are $87 \%$ and $88 \%$. At a remote mountain site in Japan, Mt. Happo (ca. $27 \mathrm{~km}$ north-northeast of Mt. Tateyama, $36^{\circ} 42^{\prime} \mathrm{N}, 137^{\circ} 48^{\prime} \mathrm{E}, 1850 \mathrm{~m}$ a.s.1.), the $\mathrm{EC}+\mathrm{OC}$ concentration was $52 \%$ of the $\mathrm{SO}_{4}^{2-}+\mathrm{NH}_{4}^{+}$concentration (Katsuno et al., 1996). Consequently, $\mathrm{SO}_{4}^{2-}+\mathrm{NH}_{4}^{+}$aerosols at mountain sites constitute the major portion of total aerosol concentrations. Combined with the discussion presented above, increasing $\mathrm{SO}_{2}$ emissions in China might engender the increase of $\mathrm{SO}_{4}^{2-}$ aerosols and total aerosol concentrations at Mt. Tateyama.

Observed submicrometer volume concentrations at Mt. Tateyama were compared with aerosol concentrations simulated as CNTL total (upper panel) and $\mathrm{SO}_{4}^{2-}$ (lower panel) from China, as portrayed in Fig. 8. Regression analysis for the upper panel indicated a significant correlation at the $99 \%$ confidence level. Average concentrations of submicrometer aerosol volume and CNTL total are, respectively, $1.8 \mu \mathrm{m}^{3} \cdot \mathrm{cm}^{-3}$ and $7.3 \mu \mathrm{g} \cdot \mathrm{m}^{-3}$. Assuming that all aerosols consist only of ammonium sulfate (density $=1.8 \mathrm{~g} \mathrm{~cm}^{-3}$ ), the observed volume concentration corresponds to $3.2 \mu \mathrm{g} \cdot \mathrm{m}^{-3}$. The OPC data used for this study cover the limited size range of $0.3-1.0 \mu \mathrm{m}$. Therefore, the simulated aerosol concentration agreed well within a factor of 2 .
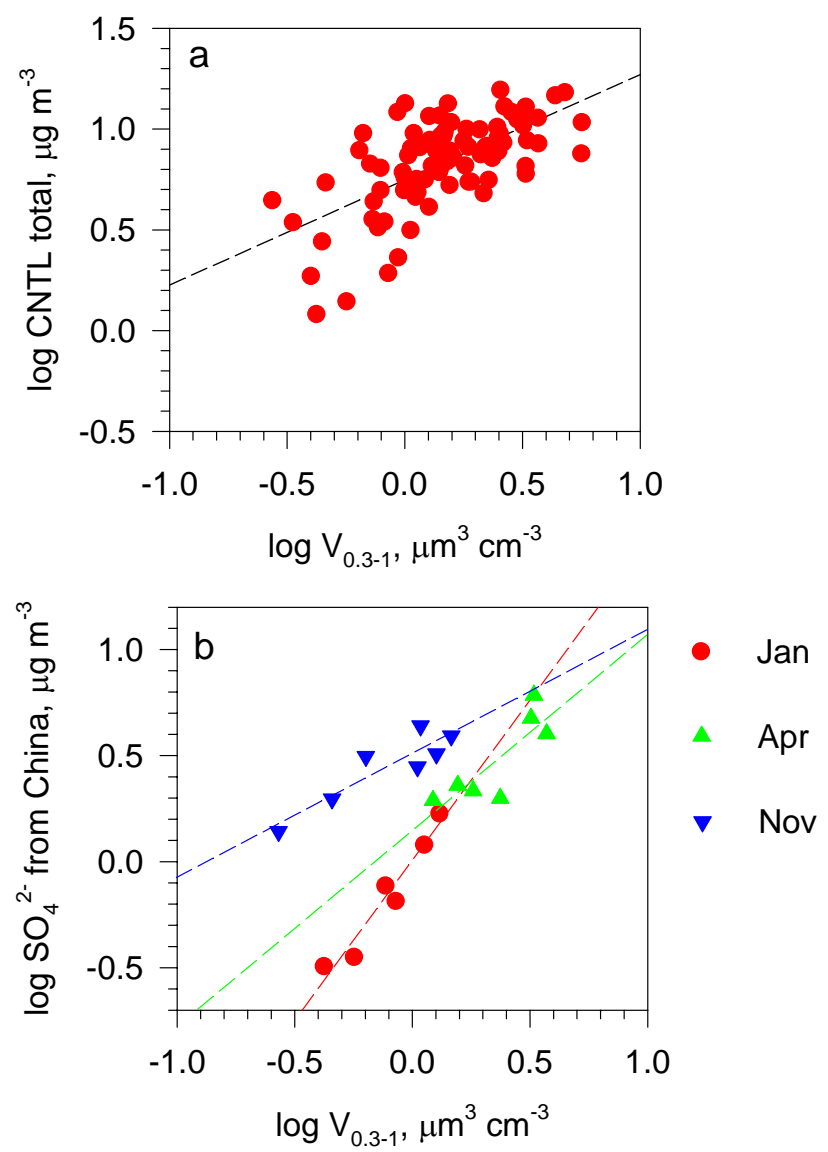

Fig. 8. Scatter plots of submicrometer volume concentration versus (upper panel) simulated total aerosol concentrations for the study period with all sources (CNTL total), and (lower panel) $\mathrm{SO}_{4}^{2-}$ aerosol concentrations derived from China for January, April, and November. Dotted lines show results of the least-squares fitting.

The lower panel of Fig. 8 portrays relations between $\mathrm{SO}_{4}^{2-}$ concentrations from China and submicrometer volume concentrations at Mt. Tateyama. All relations in the lower panel were significant at the $95 \%$ confidence level. Statistical information for single and double month combinations is given in Table 3. No significant relation was found for other months. Months presented in Table 3 belong winter to spring, suggesting that the direct effect of $\mathrm{SO}_{4}^{2-}$ aerosols from China is dominant during winter to spring rather than in summer. Slopes between volume concentrations and simulated Chinese $\mathrm{SO}_{4}^{2-}$ concentrations in the lower panel of Fig. 8 differed among seasons. The $\mathrm{SO}_{2}$ emissions were fixed at a constant level during the year for our model system. Therefore, changing slopes in Fig. 8b suggest that $\mathrm{SO}_{2}$ emission and contributions from other aerosol species might differ seasonally.

On the other hand, although the concentration of $\mathrm{SO}_{4}^{2-}$ from China is higher during the warm season (Fig. 7), its contribution to the CNTL total is not constant. To explain 
Table 3. Results of regression analysis between $\mathrm{SO}_{4}^{2-}$ from China and monthly volume concentration at Mt. Tateyama.

\begin{tabular}{lrcc}
\hline month & $n^{1}$ & $r^{2}$ & $\mathrm{SL}^{3}$ \\
\hline Jan & 6 & 0.97 & 0.1 \\
Apr & 7 & 0.79 & 2.2 \\
Nov & 7 & 0.90 & 0.5 \\
Jan + Feb & 13 & 0.71 & 0.7 \\
Feb + Mar & 15 & 0.52 & 4.5 \\
Mar + Apr & 15 & 0.68 & 0.5 \\
Oct + Nov & 14 & 0.59 & 2.8 \\
Nov + Dec & 12 & 0.70 & 1.1 \\
Dec + Jan & 11 & 0.61 & 4.8 \\
\hline
\end{tabular}

1 number of data;

2 correlation coefficient;

3 significant level in $\%$.

Fitting was performed using logarithms of the data.

the differing contribution from China according to the season, daily five-day backward air trajectories in June (left column: $a$ for 2006, $c$ for 2007, and $e$ for 2008) and December (right column: $b$ for 2006, $d$ for 2007, and $f$ for 2008) are depicted in Fig. 9. The starting height of the trajectories was set at $2500 \mathrm{~m}$ above sea level. Trajectories were calculated using HYSPLIT (Draxler and Rolph, 2003). Figure 9 depicts that major source areas and the transport distance during five days vary with the season. In December, most trajectories were transported from the west of $100^{\circ} \mathrm{E}$ or the north of $60^{\circ} \mathrm{N}$, suggesting the constant influence of northwesterly winds on aerosol transport. On the other hand, the coastal areas of eastern China, and Korea and Japan became the dominant source regions in June, with some trajectories other than this area. These results that, not only Chinese sources, but multiple source areas contribute to aerosols at Mt. Tateyama in June. In addition, the source of aerosols changes from year to year. For example, four trajectories were derived from the west of $100^{\circ} \mathrm{E}$ or the north of $60^{\circ} \mathrm{N}$ in June in 2006, with five in 2007 and eight in 2008. Consequently, seasonal and year-to-year variability in source areas engenders high variation in the contribution of aerosols from China during warm seasons, even though the average concentrations of aerosols derived from China were high.

Finally, we would like to add a comment related to $\mathrm{SO}_{2}$ emission trends in China. As described earlier, the winter minimum of submicrometer volume concentrations showed an increasing trend until 2007 or 2008 (0.98 and $0.82 \mu \mathrm{m}^{-3} \mathrm{~cm}^{-3}$ for December 2006 and December 2007, respectively). However, the value of winter the minimum during the 2008-2009 season was $0.64 \mu \mathrm{m}^{-3} \cdot \mathrm{cm}^{-3}$ (December 2008). According to official news releases from the Ministry of Environmental Protection in China (MEP, 2009), $\mathrm{SO}_{2}$ emissions in China seemed to decrease slightly for 2008 because of installation of desulfurization facilities and the
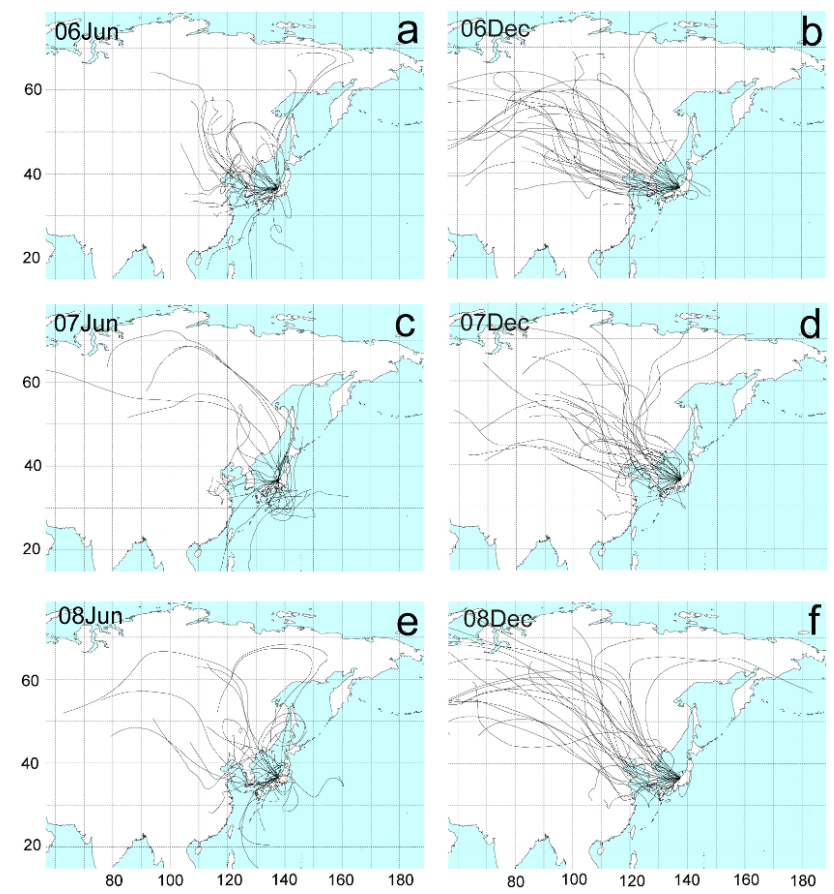

Fig. 9. Five-day backward air trajectories from Mt. Tateyama obtained using HYSPLIT for June (left column, (a) for 2006, (c) for 2007, and (e) for 2008) and December (right column, (b) for 2006, (d) for 2007, and (f) for 2008).

progressive shutting down of small power plants. That recent $\mathrm{SO}_{2}$ reduction in China accords with our observation, but a more extensive record is needed for future studies to confirm this trend.

\section{Summary and conclusions}

Submicrometer $(0.3-1.0 \mu \mathrm{m})$ aerosol data obtained at Mt. Tateyama for the recent decade showed clear seasonal and interannual variations. Monthly average volume concentrations of submicrometer aerosols were high in spring to early summer and low in winter. Significant increasing trends at a $95 \%$ confidence level were found for volume concentrations during winter-spring. No trend was found in local precipitation or air temperature. Simulated aerosol concentrations at Mt. Tateyama, as calculated from results of regional aerosol modeling using an emissions inventory up to 2005 showed similar seasonal variation and winterspring increasing trends to those of observed aerosol concentration. A higher contribution of Chinese-derived anthropogenic aerosol concentration was estimated for winterspring using the model analysis. Because $\mathrm{SO}_{4}^{2-}$ is the dominant component of total anthropogenic aerosols, these results suggest that increasing anthropogenic emissions, especially 
those of $\mathrm{SO}_{2}$ in China, engender enhancement of submicrometer aerosols over Japan, especially during winterspring.

Acknowledgements. We are indebted to the staff of Tateyama Kurobe Kanko (TKK) and Tateyama Caldera SABO Museum for assisting our work at Mt. Tateyama. The authors gratefully acknowledge the NOAA Air Resources Laboratory (ARL) for provision of the HYSPLIT transport and dispersion model and READY website (http://www.arl.noaa.gov/ready.php) used for this study. This work was performed with the support of a Grant-in-Aid for Scientific Research in Priority Areas, Grant No. 18067005 (W-PASS), provided by the Ministry of Education, Culture, Sports, Science and Technology, Japan, and by Grants-in-Aid for Scientific Research (C) 1368061, (B) 20310009, and (A) 20244078 from the Ministry of Education, Culture, Sports, Science and Technology. This research is a contribution of IGBP/SOLAS activity. This work was supported by the Global Environment Research Fund of the Ministry of the Environment, Japan (S-7).

Edited by: E. Weingartner

\section{References}

Akimoto, H.: Global air quality and pollution, Science, 302, 17161719, 2003.

Binkowski, F. S. and Shankar, U.: The Regional Particulate Matter Model 1. Model description and preliminary results, J. Geophys. Res., 100(D12), 26191-26209, 1995.

Byun, D. W. and Schere, K. L.: Review of the governing equations, computational algorithms, and other components of the Models3 Community Multiscale Air Quality (CMAQ) modeling system, Appl. Mech. Rev., 59, 51-77, 2006.

Carter, W.: Implementation of the SAPRC-99 chemical mechanism into the models-3 framework, Report to the United States Environmental Protection Agency, 29 January, 2000.

Collaud-Coen, M., Weingartner, E., Nyeki, S., Cozic, J., Henning, S., Verheggen, B., Gehrig, R., and Baltensperger, U.:, Long-term trend analysis of aerosol variables at the highalpine site Jungfraujoch, J. Geophys. Res., 112, D13213, doi:10.1029/2006JD007995, 2007.

Draxler, R. R. and Rolph, G. D.: HYSPLIT (HYbrid Single-Particle Lagrangian Integrated Trajectory) Model access via NOAA ARL READY Website http://www.arl.noaa.gov/ HYSPLIT.php, last access: 2 December 2009, NOAA Air Resources Laboratory, Silver Spring, MD, 2003.

Gilbert, R. O.: Statistical Methods for Environmental Pollution Monitoring, Van Nostrand Reinhold, New York, NY, 1987.

He, Y., Uno, I., Wang, Z., Ohara, T., Sugimoto, N., Shimizu, A., Richter, A., and Burrows, J. P.: Variations of the increasing trend of tropospheric $\mathrm{NO}_{2}$ over central east China during the past decade, Atmos. Environ., 41, 4865-4876, 2007.

Heidam, N. Z., Wahlin, P., and Kemp, K.: Arctic aerosols in Greenland, Atmos. Environ., 17/18, 3029-3036, 1993.

Huebert, B. J., Phillips, C. A., Zhuang, L., Kjellström, E., Rodhe, H., Feichter, J., and Land, C.: Long-term measurements of freetropospheric sulfate at Mauna Loa: Comparison with global model simulations, J. Geophys. Res., 106(D6), 5479-5492, 2001.
International Energy Agency: Energy Balances of OECD Countries and Energy Balances of Non-OECD Countries, CD-ROM, Paris, 2007.

Kalnay, E., Kanamitsu, M., Kistler, R., Collins, W., Deaven, D., Gandin, L., Iredell, M., Saha, S., White, G., Woollen, J., Zhu, Y., Leetmaa, A., Reynolds, R., Chelliah, M., Ebisuzaki, W., Higgins, W., Janowiak, J., Mo, K. C., Ropelewski, C., Wang, J., Jenne, R., and Joseph, D.: The NCEP/NCAR 40-Year Reanalysis Project, B. Am. Meteorol. Soc., 77, 437-471, 1996.

Kaneyasu, N., Igarashi, Y., Sawa, Y., Takahashi, H., Takada, H., Kumata, H., and Höller, R.: Chemical and optical properties of 2003 Siberian forest fire smoke observed at the summit of Mt. Fuji, Japan, J. Geophys. Res., 112, D13214, doi:10.1029/2007 JD008544, 2007.

Katayama, M., Ohara, T., Uno, I., and Hara, H.: Model analysis of inter-annual variations of sulfur depositions in Japan, J. Jpn. Soc. Atmos. Environ., 43, 136-146, 2008.

Katsuno, T., Satsumabayashi, H., Sasaki, K., Shinano, M., Ota, M., Hatakeyama, S., and Murano, K.: Chemical components of airborne particulate matter and acid deposition in Happoone and Nagano city, J. Jpn. Soc. Atmos. Environ., 31, 282-291, 1996.

Kazahaya, K., Shinohara, H., Saito, G., Odai, M., Mori, H., Nakahori, Y., Iino, H., and Hiyabayashi, J.: Extremely large amount of volcanic gas emissions from Miyakajima volcano, Japan, edited by: Kinoshita, K., Researching eruption clouds of volcanic island chains, Kagoshima University Research Center for the Pacific Islands, Occasional papers, 37, 24-31, 2003.

Kido, M., Osada, K., Matsunaga, K., and Iwasaka, Y.: Diurnal variation of ionic aerosol species and water-soluble gas concentrations at a high-elevation site in the Japanese Alps, J. Geophys. Res., 106, 17335-17345, 2001.

Kistler, R., Kalnay, E., Collins, W., Saha, S., White, G., Woollen, J., Chelliah, M., Ebisuzaki, W., Kanamitsu, M., Kousky, V., van den Dool, H., Jenne, R., and Fiorino, M.: The NCEP-NCAR 50year reanalysis: Monthly means CD-ROM and documentation, B. Am. Meteorol. Soc., 82, 247-267, 2001.

Menon, S., Hansen, J., Nazarenko, L., and Luo, Y.: Climate effects of black carbon aerosols in China and India, Science, 297, 2250 2253, 2002.

Ministry of Environmental Protection: The State of the Environment of China in 2008, http://english.mep.gov.cn/News_service/ news_release/200906/t20090618_152932.htm, last access: 2 December 2009, 2009.

Nenes, A., Pandis, S. N., and Pilinis, C.: ISORROPIA: A new thermodynamic equilibrium model for multiphase multicomponent inorganic aerosols, Aquat. Geochem., 4, 123-152, 1998.

Nyeki, S., Li, F., Weingartner, E., Streit, N., Colbeck, I., Gäggeler, H. W., and Baltensperger, U.: The background aerosol size distribution in the free troposphere: An analysis of the annual cycle at a high-alpine site, J. Geophys. Res., 103(D24), 31749-31761, 1998.

Ohara, T., Akimoto, H., Kurokawa, J., Horii, N., Yamaji, K., Yan, X., and Hayasaka, T.: An Asian emission inventory of anthropogenic emission sources for the period 1980-2020, Atmos. Chem. Phys., 7, 4419-4444, 2007, http://www.atmos-chem-phys.net/7/4419/2007/.

Osada, K., Kido, M., Iida, H., Matsunaga, K., Iwasaka, Y., Nagatani, M., and Nakada, H.: Seasonal variation of free tropospheric aerosol particles at Mt. Tateyama, central Japan, J. 
Geophys. Res., 108 (D23), 8667, doi:10.1029/2003JD003544, 2003.

Pielke, R. A., Cotton, W. R., Walko, R. L., Tremback, C. J., Lyons, W. A., Grasso, L. D., Nicholls, M. E., Moran, M. D., Wesley, D. A., Lee, T. J., and Copeland, J. H.: A comprehensive meteorological modeling system-RAMS, Meteorol. Atmos. Phys., 49, 69-91, 1992.

Prospero, J. M., Savoie, D. L., and Arimoto, R.: Long-term record of nss-sulfate and nitrate in aerosols on Midway Island, 1981-2000: Evidence of increased (now decreasing?) anthropogenic emissions from Asia, J. Geophys. Res., 108(D1), 4019, doi:10.1029/2001JD001524, 2003.

Richter, A., Burrows, J. P., Nüß, H., Granier, C., and Niemeier, U.: Increase in tropospheric nitrogen dioxide over China observed from space, Nature, 437, 129-132, doi:10.1038/nature04092, 2005.

Schell, B., Ackermann, I. J., Hass, H., Binkowski, F. S., and Ebel, A.: Modeling the formation of secondary organic aerosol within a comprehensive air quality model system, J. Geophys. Res., 106(D22), 28275-28293, 2001.

Streets, D. G., Bond, T. C., Carmichael, G. R., Fernandes, S. D., Fu, Q., He, D., Klimont, Z., Nelson, S. M., Tsai, N. Y., Wang, M. Q., Woo, J. H., and Yarber, K. F.: An inventory of gaseous and primary aerosol emissions in Asia in 2000, J. Geophys. Res., 108(D21), 8809, doi:10.1029/2002JD003093, 2003.

Streets, D. G., Yarber, K. F., Woo, J.-H., and Carmichael, G. R.: Biomass burning in Asia: Annual and seasonal estimates and atmospheric emissions, Global Biogeochem. Cy., 17(4), 1099, doi:10.1029/2003GB002040, 2003.

Sudo, K., Takahashi, M., Kurokawa, J., and Akimoto, H.: CHASER: A global chemical model of the troposphere: 1. Model description, J. Geophys. Res., 107(D17), 4339, doi:10.1029/2001JD001113, 2002.

United Nations: Statistical Yearbook, issue 49, New York, 2005.

United Nations: Statistical Yearbook, issue 50, New York, 2006.

Uno, I., Mori, J., Utsunomiya, A., and Wakamatsu, S.: Numerical analysis of sulfate high concentration observed during the Baiu season, J. Jpn. Soc. Atmos. Environ., 33, 109-116, 1998.

Uno, I., Ohara, T., Sugata, S., Kurokawa, J., Furuhashi, N., Yamaji, K., Tanimoto, N., Yumimoto, K., and Uematsu, M.: Development of the RAMS/CMAQ Asian scale chemical transport modeling system, J. Jpn. Soc. Atmos. Environ., 40, 148-164, 2005.
Uno, I., He, Y., Ohara, T., Yamaji, K., Kurokawa, J.-I., Katayama, M., Wang, Z., Noguchi, K., Hayashida, S., Richter, A., and Burrows, J. P.: Systematic analysis of interannual and seasonal variations of model-simulated tropospheric $\mathrm{NO}_{2}$ in Asia and comparison with GOME-satellite data, Atmos. Chem. Phys., 7, 16711681, 2007, http://www.atmos-chem-phys.net/7/1671/2007/.

Uno, I., Uematsu, M., Hara, Y., He, Y. J., Ohara, T., Mori, A., Kamaya, T., Murano, K., Sadanaga, Y., and Bandow, H.: Numerical study of the atmospheric input of anthropogenic total nitrate to the marginal seas in the western North Pacific region, Geophys. Res. Lett., 34, L17817, doi:10.1029/2007GL030338, 2007b.

van $\operatorname{der}$ A, R. J., Peters, D. H. M. U., Eskes, H., Boersma, K. F., Van Roozendael, M., De Smedt, I., and Kelder, H. M.: Detection of the trend and seasonal variation in tropospheric $\mathrm{NO}_{2}$ over China, J. Geophys. Res., 111, D12317, doi:10.1029/2005JD006594, 2006.

van der A, R. J., Eskes, H. J., Boersma, K. F., van Noije, T. P. C., Van Roozendael, M., De Smedt, I., Peters, D. H. M. U., and Meijer, E. W.: Trends, seasonal variability and dominant $\mathrm{NO}_{\mathrm{x}}$ source derived from a ten year record of $\mathrm{NO}_{2}$ measured from space, J. Geophys. Res., 113, D04302, doi:10.1029/2007JD009021, 2008. van der Werf, G. R., Randerson, J. T., Giglio, L., Collatz, G. J., Kasibhatla, P. S., and Arellano Jr., A. F.: Interannual variability in global biomass burning emissions from 1997 to 2004, Atmos. Chem. Phys., 6, 3423-3441, 2006, http://www.atmos-chem-phys.net/6/3423/2006/.

Yamaji, K., Ohara, T., Uno, I., Tanimoto, H., Kurokawa, J., and Akimoto, H.: Analysis of the seasonal variation of ozone in the boundary layer in East Asia using the Community Multiscale Air Quality model: What controls surface ozone levels over Japan?, Atmos. Environ., 40, 1856-1868, 2006.

Yamaji, K., Ohara, T., Uno, I., Kurokawa, J., Pochanart, P., and Akimoto, H.: Future prediction of surface ozone over east Asia using Models-3 Community Multiscale Air Quality Modeling System and Regional Emission Inventory in Asia, J. Geophys. Res., 113, D08306, doi:10.1029/2007JD008663, 2008.

Whiteman, C. D.: Mountain Meteorology, Oxford University Press, Oxford, 355 p., 2000. 